\title{
The Effects of Tenure, Teacher Certification, and Work Motivation on Special Needs Teacher Performance
}

\author{
Diajeng Tyas Pinru Phytanza ${ }^{1}$, Erick Burhaein ${ }^{2, *}$ \\ ${ }^{1}$ Department of Special Education, Faculty of Education, Universitas Negeri Yogyakarta, Indonesia \\ ${ }^{2}$ Doctoral of Sports Education, School of Postgraduates Studies, Universitas Pendidikan Indonesia, Indonesia
}

Received May 7, 2020; Revised June 30, 2020; Accepted July 20, 2020

\section{Cite This Paper in the following Citation Styles}

(a): [1] Diajeng Tyas Pinru Phytanza, Erick Burhaein, "The Effects of Tenure, Teacher Certification, and Work Motivation on Special Needs Teacher Performance," Universal Journal of Educational Research, Vol. 8, No. 9, pp. 4348-4356, 2020. DOI: 10.13189/ujer.2020.080962.

(b): Diajeng Tyas Pinru Phytanza, Erick Burhaein (2020). The Effects of Tenure, Teacher Certification, and Work Motivation on Special Needs Teacher Performance. Universal Journal of Educational Research, 8(9), 4348-4356. DOI: 10.13189/ujer.2020.080962.

Copyright $\bigcirc 2020$ by authors, all rights reserved. Authors agree that this article remains permanently open access under the terms of the Creative Commons Attribution License 4.0 International License

\begin{abstract}
This study aimed to determine the significant effects of tenure, teacher certification, and work motivation on the performance of special needs teachers. It was a quantitative research with a correlation research design. The study used a random sampling technique with 45 Special Needs teachers with the age range of 35-50 years. Dealing with the data collection technique, the researchers used a questionnaire for work motivation, a documentation sheet for teacher certification and job tenure, and an observation sheet for teacher performance. The data was analyzed using a product-moment correlation test with the help of SPSS version 24 . The results show that: 1) there is a significant effect of job tenure on Special Needs teacher performance; 2) there is a significant effect of teacher certification on Special Needs teacher performance; 3) there is a significant effect of work motivation on Special Needs teacher performance; and 4) there are significant effects of job tenure, teacher certification, and work motivation on Special Needs teacher performance. The research has a practical implication; Special Needs teacher performance must be supported by tenure, teacher certification, and work motivation. Further research should include other factors not mentioned in this study, which comprises of levels of education, teacher welfare, leadership, competence, work climate, and workers' compensation.
\end{abstract}

Keywords Job Tenure, Teacher Certification, Work Motivation, Teacher Performance, Special Needs Teachers

\section{Introduction}

Education is a process of building the basis of culture and human life limited by the development of values or vision, and social development [1]. Quality education is an absolute requirement that must exist to improve the nation welfare, namely in Indonesia. The world of education is currently experiencing changes related to the quality and relevance of education and the acquisition of skills with the rapid development of sophisticated technology [2]. Thus, one of the strategies is to improve the quality of human resources through education. Learning is part of an educational process in schools, so it is essential to focus on the learning objectives to be achieved [3].

Learning objectives are a behavior of learning outcomes expected to occur, be owned, or be mastered by students after participating in certain learning activities [4-5]. In Special Needs, in the country where the study was done, learning objectives should be achieved with a variety of disabilities include intellectual disabilities, learning disabilities, Attention-Deficit/Hyperactivity Disorders (ADHD), emotional and behavioral disorders, communication disorders, deaf and hard of hearing, blind and low vision, Autism Spectrum Disorders (ASD), severe and multiple disabilities, and special gifts and talents [6]. The achievement of learning objectives cannot be 
separated from the performance of Special Needs teachers.

One of the factors affecting teaching performance is job tenure, which is the period or length of time an employee devotes himself to a work unit or organization [7]. It is also, it is the total experience learned by a person from events that pass in life in a work unit or organization [8].

The teacher's job tenure is calculated from when the teacher was first appointed as a teacher in Special Needs. The longer the tendency to work, the more experience they have, the better will be the performance [9]. If a person has limited work experience, she/he will have a low quality of performance and skills. Job tenure is also influenced by one's working age (productive age). Someone who is still in a productive period certainly has a higher level of productivity than someone older with physical limitations [10].

On the other hand, too long job tenure without promotion and variations in work will make somebody unenthusiastic in doing a particular job [11]. In the country studied, a teacher has very little chance to get a job promotion. These conditions will surely have an impact on the lack of motivation to teach so that the performance of Special Needs teachers has decreased in quality.

Efforts to improve teacher quality are widely carried out by the government with the legal instruments and operational policies. The government has made a program to improve teacher quality and professionalism, namely teacher certification. It is a process of awarding certificates to teachers who have met the qualification standard and competency standard [12]. Certification is a process of giving teacher and lecturer certificates or formal proof as professional staff. In general, teacher certification is mandated by Law No. 20 of 2003 concerning the National Education System [13]. In particular, teacher certification refers to Law No. 14 of 2005 in Articles 8 and 11 concerning Teachers and Lecturers.

The aims of the Government to conduct a teacher certification program are (1) to determine the eligibility of teachers in carrying out their duties as professional educators, (2) to improve the process and quality of educational outcomes, (3) to increase teacher's dignity, and (4) to improve teacher professionalism [15]. Realizing this, teachers must prepare themselves for training for professional development in order to be able to take teacher certification. Based on this, the teacher certification program should have a positive impact on teacher quality improvement. In addition, another factor affecting Special Needs teacher performance is work motivation. Motivation means the tendency and selectivity of behavior controlled by its relationship between the consequences and tendency to set goals until they are reached [16-17]. In general, work motivation can be interpreted as a motive or drive to do something.

On the other hand, work motivation is something arousing enthusiasm in the workplace [18-19]. Motivation consists of two types, namely, intrinsic and extrinsic motivation [20]. Extrinsic motivation and intrinsic motivation are interrelated, but each person has different motivation [21]. For example, extrinsically, an employee is motivated to do his/her work to earn money [22]. According to previous research, intrinsic and extrinsic motivation has been proven to be significant in improving employee performance [23].

Based on various theoretical studies mentioned above, teacher performance is generally influenced by several independent variables, including job tenure, teacher certification, and work motivation. The first is teacher's job tenure; the relatively long job tenure generally does not affect the spirit at work, so it impacts the teaching performance of Special Needs teachers. Secondly, teacher certification, a program to improve teacher quality, does not always meet the expectation. Some certified Special Needs teachers only want to obtain professional allowances. The third is work motivation; their motivation to work arises due to the teacher certification program, although there are findings [12] that professional allowances do not guarantee teacher performance. These problems raise the following research questions:

1) Is there any significant effect of job tenure on Special Needs teacher performance?

2) Is there any significant effect of teacher certification on Special Needs teacher performance?

3) Is there any significant effect of work motivation on Special Needs teacher performance?

4) Is there any significant effect of job tenure, teacher certification, and work motivation on Special Needs teacher performance?

\section{Materials and Method}

\subsection{Participants}

The participants of this study were Special Needs teachers with the status of Civil Servant in the Special Region of Yogyakarta (DIY) in five regencies/cities, namely Sleman Regency, Kulon Progo Regency, Yogyakarta City, Bantul Regency, and Gunungkidul Regency. This research used a cluster random sampling technique. The sampling technique was based on the selection of groups or sample groups [24]. In this technique, the participants were randomly selected; they were five teachers from each district/city cluster. Thus, the total participants were 45 Special Needs teachers $(\mathrm{N}=45)$ with an age range of $35-50$ years $(\mathrm{M}=40.04, \mathrm{SD}=3.21)$.

\subsection{Research Method}

This research used a quantitative approach with a correlational research design [24]. This approach was 
selected because it was in accordance with the problem revealed. The problem existing in the world of education in Indonesia is closely related to the needs to achieve good learning standards through work performance. This research method can be used to reveal problems that have occurred without manipulating research. There are three independent variables in this study, namely, job tenure, teacher certification, and work motivation, and one dependent variable which is teacher performance.

\subsection{Instrument}

\subsubsection{Job Tenure}

The instrument to measure job tenure or years of service was a documentation sheet. Table 1 presents the job tenure documentation sheet.

Table 1. Documentation Sheet of Job Tenure

\begin{tabular}{lcc}
\hline No & Indicator/Job Tenure & Option (Answer) \\
\hline 1. & $2-5$ years & $\ldots$ \\
\hline 2. & $6-9$ years & $\ldots$ \\
\hline 3. & $10-13$ years & $\ldots$ \\
\hline 4. & $14-17$ years & $\ldots$ \\
\hline 5. & $18-21$ years & $\ldots$ \\
\hline 6. & years & $\ldots$ \\
\hline 7. & $>25$ years & $\ldots$ \\
\hline
\end{tabular}

\subsubsection{Teacher Certification}

The instrument for collecting data on teacher certification was a documentation sheet (see Table 2).

Table 2. Documentation Sheet of Teacher Certification

\begin{tabular}{lll}
\hline \multirow{2}{*}{ No } & \multirow{2}{*}{ Teacher Name } & \multicolumn{2}{c}{ Teacher Certificate } \\
& & Certified Non-Certified \\
\hline 1. & \\
\hline 2. & \\
\hline$\ldots$. & \\
\hline
\end{tabular}

\subsubsection{Work Motivation}

The instrument for measuring work motivation was a questionnaire. It used a Likert scale with four scales. This instrument was previously validated through an expert judgment by two experts. To reach an agreement, two experts were enough [25]. Then, the reliability was tested with a Cronbach Alpha value of 0.943. The work motivation questionnaire consisted of 40 statements (see Table 3).

\subsubsection{Teacher Performance}

The instrument for measuring teacher performance was an observation sheet. It used a Likert scale with five scales. This instrument was previously validated through an expert judgment by two experts. To reach an agreement, two experts were enough [25]. Then, the reliability was tested with a Cronbach Alpha value of 0.938. The teacher performance observation sheets consisted of 20 reports (see Table 4).

Table 3. Questionnaire Blueprint of Work Motivation

\begin{tabular}{|c|c|c|c|c|c|}
\hline \multirow{2}{*}{ Variable } & \multirow{2}{*}{ Factor } & \multirow{2}{*}{ Indicator } & \multicolumn{2}{|c|}{ Statement Items } & \multirow{2}{*}{ Tota } \\
\hline & & & $(+)$ & $(-)$ & \\
\hline \multirow{10}{*}{ Work Motivation } & \multirow{5}{*}{ Internal } & Spirit at work & 2 & 2 & 4 \\
\hline & & Loyalty at work & 2 & 2 & 8 \\
\hline & & Pride to achieved results & 2 & 2 & 12 \\
\hline & & $\begin{array}{c}\text { Potential and Skill } \\
\text { Development }\end{array}$ & 2 & 2 & 16 \\
\hline & & Freedom to give opinions & 2 & 2 & 20 \\
\hline & \multirow{5}{*}{ External } & $\begin{array}{c}\text { Salary/ } \\
\text { incentive/ } \\
\text { wage }\end{array}$ & 2 & 2 & 24 \\
\hline & & Present/bonus & 2 & 2 & 28 \\
\hline & & Award/Compliment & 2 & 2 & 32 \\
\hline & & Work Atmosphere & 2 & 2 & 36 \\
\hline & & Working Relationship & 2 & 2 & 40 \\
\hline
\end{tabular}


Table 4. Observation Blueprint of Teacher Performance

\begin{tabular}{|c|c|c|c|c|}
\hline Variable & Factor & Indicator & Question Item & Total \\
\hline \multirow{8}{*}{$\begin{array}{c}\text { Teacher } \\
\text { Performance }\end{array}$} & Pre-learning Activities & Checking student readiness & 2 & 2 \\
\hline & \multirow{6}{*}{ Main Activities } & Mastering learning materials & 3 & 5 \\
\hline & & Using Learning strategy/approach & 4 & 9 \\
\hline & & Using learning resources/media & 3 & 12 \\
\hline & & Creating exciting and engaging learning & 2 & 14 \\
\hline & & Assessing the learning process and outcomes & 2 & 16 \\
\hline & & Using appropriate language & 2 & 18 \\
\hline & Closing & Checking all assignments & 2 & 20 \\
\hline
\end{tabular}

\subsection{Data Collection Technique}

To collect the data, the researchers did a survey, documentation, and observation. The survey was carried out by distributing a questionnaire with a series of questions or written statements to respondents [24]. It was used to collect data on the work motivation variable. In this data collection, 45 teachers were asked to fill in a work motivation questionnaire; there were 40 questions revealing the teacher's extrinsic and intrinsic variables.

Documentation was a technique for collecting data on things or variables in the form of notes, transcripts, books, newspapers, magazines, inscriptions, meetings, and agendas [24]. In this study, documentation was used to collect data on variables of work, years of service, and teacher certification. As many as 45 teachers were asked to fill in the documentation sheet about job tenure and teacher certification.

The last technique was observation as the complexity of biological and psychological processes, the most important of which is observation and memory [24]. In this study, 45 teachers were observed to collect data on the teacher performance variable.

\subsection{Data Analysis Technique}

There were two data analysis techniques in this study. To test the first $\left(r_{x 1 y}\right)$, second $\left(r_{x 2 y}\right)$, and the third $\left(r_{x 3 y}\right)$ hypothesis used a product-moment correlation analysis. The fourth hypothesis $\left(\mathrm{r}_{\mathrm{x} 123} \mathrm{y}\right)$ was tested using multiple linear regression. The hypothesis was accepted, if $\mathrm{p}<0.05$, and the hypothesis was rejected, if $p>0.05$. The data analysis was assisted with SPSS version 24 .

\section{Results}

\subsection{Job Tenure}

The description of the respondent characteristics based on job tenure is presented in table 5 :
Table 5. Data on respondent characteristics based on job tenure

\begin{tabular}{cccc}
\hline No. & Indicator/Job Tenure & F & $\mathbf{( \% )}$ \\
\hline 1. & $2-5$ years & 0 & 0.0 \\
2. & $6-9$ years & 3 & 6.67 \\
3. & $10-13$ years & 5 & 11.11 \\
4. & $14-17$ years & 5 & 11.11 \\
5. & $18-21$ years & 8 & 17.78 \\
6. & years & 14 & 31.11 \\
7. & $>25$ years & 10 & 22.22 \\
\hline
\end{tabular}

The results in table 5 above show that there are no teachers $(0 \%)$ with $2-5$ years of service. Meanwhile, there are 3 teachers $(6.67 \%)$ with $6-9$ years of service, 5 teachers (11.1\%) with $10-13$ years of service, 5 teachers $(11.1 \%)$ with 14-17 years of service, 8 teachers $(17.78 \%)$ with $18-21$ years of service, 14 teachers $(31.11 \%)$ with $22-26$ years of service, and 10 teachers (22. 22\%) with more than 25 years of service. It can be concluded that the majority of Special Needs teachers has job tenure of more than 22 years $(53.33 \%)$.

\subsection{Teacher Certification}

The description of the respondent characteristics based on Special Needs teacher certification is presented in table 6:

Table 6. Teacher Certification

\begin{tabular}{ccc}
\hline Teacher Certification & F & (\%) \\
\hline Certified & 8 & 17.78 \\
Non-certified & 37 & 82.22 \\
\hline Total & 45 & 100.0 \\
\hline
\end{tabular}

The results in table 6 show that as many as 8 teachers $(17.78 \%)$ have not been certified, and there are 22 certified teachers $(82.22 \%)$. It can be concluded that most Special Needs teachers are certified $(82.22 \%)$. 


\subsection{Work Motivation}

Based on table 7, it is perceived that there are 35 teachers $(77.78 \%)$ with work motivation in the high category, 10 teachers $(22.22 \%)$ with work motivation in the medium category, and there are no teachers with work motivation in the low category $(0.0 \%)$. In conclusion, most Special Needs teachers have a strong motivation to work $(77.78 \%)$.

Table 7. Work Motivation Variable

\begin{tabular}{ccccc}
\hline No. & Score Range & F & $\mathbf{( \% )}$ & Category \\
\hline 1. & $\mathrm{X} \geq 114.00$ & 35 & 77.78 & High \\
2. & $76.00 \leq \mathrm{X}<114.00$ & 10 & 22.22 & Medium \\
3. & $\mathrm{X}<76.00$ & 0 & 0.0 & Low \\
\hline & Total & 45 & 100.0 & \\
\hline
\end{tabular}

\subsection{Teacher Performance}

The teacher performance variable was classified into three categories (High, Medium, and Low), and the results found are presented in Table 8:

Table 8. Teacher Performance

\begin{tabular}{ccccc}
\hline No. & Score Range & $\mathrm{F}$ & $(\%)$ & Category \\
\hline 1. & $\mathrm{X} \geq 3.67$ & 45 & 100.0 & High \\
2. & $2.33 \leq \mathrm{X}<3.67$ & 0 & 0.0 & Medium \\
3. & $\mathrm{X}<2.33$ & 0 & 0.0 & Low \\
\hline & Total & 45 & 100.0 & \\
\hline
\end{tabular}

Based on table 8 , the performance of 45 teachers $(100.0 \%)$ is in the high category, and there are no teachers $(0.0 \%)$ with performance in the medium and low categories. It can be concluded that all the Special Needs teacher performance is in the high category $(100.0 \%)$.

\subsection{Hypothesis Testing: Product-Moment Correlation Analysis}

The Karl Pearson Product-moment correlation analysis is used to test the hypotheses. Hypothesis $1-3$ are as follows:
Hypothesis 1: There is a significant effect of job tenure on Special Needs teacher performance.

Hypothesis 2: There is a significant effect of teacher certification on Special Needs teacher performance.

Hypothesis 3: There is a significant effect of work motivation on Special Needs teacher performance.

The product-moment correlation test result is presented in table 9.

The correlation coefficient $r_{x 1 y}$ shows the value of 0.581 , which indicates that job tenure and years of service have a positive correlation with the performance of Special Needs teachers. The determination coefficient $\left(R^{2}{ }_{x 1 y}\right)$ is 0.222 , which means that the job tenure variable has an effect of $22.2 \%$ on the teacher performance variable, and the rest is influenced by other variables (factors). The significance value of $r_{x 1 y}$ is 0.003 and less than $0.05(p<0.05 ; 0.003$ $<0.05$ ); thus, Hypothesis 1 is accepted. Which means, that there is a significant effect of job tenure on Special Needs teacher performance.

The correlation coefficient $\mathrm{r} \times 2 \mathrm{y}$ shows the value of 0.596 , which indicates that teacher certification has a positive correlation with Special Needs teacher performance. The determination coefficient $\left(\mathrm{R}_{\mathrm{x} \text { 1y) }}^{2}\right.$ is 0.236 ; the teacher certification variable has an effect of $23.6 \%$ on the teacher performance variable, and the rest is influenced by other variables (factors). The significance value of $\mathrm{r}_{\mathrm{x} 2 \mathrm{y}}$ is 0.002 or less than $0.05(\mathrm{p}<0.05 ; 0.002<0.05)$; therefore, Hypothesis 2 is accepted, meaning that, there is a significant effect of teacher certification on the performance of Special Needs teachers.

The correlation coefficient is $r_{x 3 y}$ with a value of 0.621 , which indicates that work motivation has a positive correlation with the performance of Special Needs teachers. The determination coefficient $\left(\mathrm{R}^{2}{ }_{\mathrm{x} 1 \mathrm{y}}\right)$ is 0.375 , which means that work motivation gives $37.5 \%$ effect on the teacher performance variable, and the rest is influenced by other variables (factors). The significance value of $r_{x 3 y}$ is 0.001 and less than 0.05 ( $<<0.05 ; 0.001<0.05$ ), so Hypothesis 3 is accepted. This means that there is a significant effect of work motivation on Special Needs teacher performance.

Table 9. Product-moment correlation result

\begin{tabular}{clcccc}
\hline Variable & Correlation & $\mathrm{r}$ & $\mathrm{R}^{2}$ & Sig. & Conclusion \\
\hline Job Tenure & Partial correlation & 0.581 & 0.222 & 0.003 & Significant \\
Teacher Certification & Partial correlation & 0.596 & 0.236 & 0.002 & Significant \\
Work Motivation & Partial correlation & 0.621 & 0.375 & 0.001 & Significant \\
\hline
\end{tabular}




\subsection{Hypothesis Testing: Multiple Regression Analysis}

The multiple regression analysis is selected to analyze the proposed fourth hypothesis, which 4-states that:

Hypothesis 4: There is a significant effect of job tenure, teacher certification, and work motivation on Special Needs teacher performance.

The multiple regression analysis is used to test Hypothesis 4. The following is the result of the analysis. Table 10 shows the results found.

Table 10. Summary of Multiple Regression Result

\begin{tabular}{lccl}
\hline Variable & $\begin{array}{c}\text { Regression } \\
\text { Coefficient (b) }\end{array}$ & Sig. & Conclusion \\
\hline Job Tenure & 0.002 & 0.031 & Significant \\
Teacher Certification & 0.121 & 0.027 & Significant \\
Work Motivation & 0.008 & 0.002 & Significant \\
Constant $=3.312$ & & & \\
$\mathrm{R}^{2}=0.632$ & & & \\
$\mathrm{~F}_{1}=12.521$ & & & \\
Sig. $=0.000$ & & & \\
\hline
\end{tabular}

Based on the test result, the calculated F value of 12.521 is obtained with a significance level of 0.000 . Because the significance value of $\mathrm{r}_{\mathrm{x} 123 \mathrm{y}} 0.000$ is less than 0.05 ( $\mathrm{p}<0.05$; $0.000<0.05$ ), Hypothesis 4 is accepted. Therefore, there is a significant effect of job tenure, teacher certification, and work motivation on Special Needs teacher performance.

The $\mathrm{R}^{2}$ test result in this study obtains a value of 0,632 . This shows that teacher performance is influenced (63.2\%) by job tenure, teacher certification, and work motivation, while the rest $(36.8 \%)$ is influenced by other variables (factor) not included in this study.

\section{Discussion}

\subsection{The Significant Effect of Job Tenure on Special Needs Teacher Performance}

The result shows that there is a significant effect of job tenure on Special Needs teacher performance. This means that one of the factors influencing teacher performance is job tenure/years of service. Job tenure is the whole experience learned by someone from the events that pass in the life journey in a work unit or organization [26]. Job tenure or years of service are useful to support knowledge in handling work problems, but some teachers are not ready to do new tasks and need a longer time to complete them [27].

The longer tenure has a positive impact on the level of income and experience. Also, the longer work experience has an impact on well-being. The years of service can be expressed as employee loyalty at work. Therefore, job tenure broadens the experience related to obstacles and successes. The longer the teacher's job tenure, the longer the teaching experience at school. It can be assumed that when Special Needs teachers have more experience so their students can have a better achievement in the learning objectives.

The longer the job tenure, the more experience they have, and the better the performance [28]. If an employee has limited work experience, she/he will have a low level of skills. Job tenure of a worker is also affected by age. Someone who is still in a productive period has a higher level of productivity than someone older with physical limitations [29-30].

The finding of this study is also supported by a previous study done by Rida, et al. [31], which points out that there is a significant effect of job tenure on teacher professionalism. Innovations from this study compared to previous studies include: 1) participants who are the wider research population compared to research Rida, et al. that is, this research uses five districts versus one district (previous research); 2) the participants of this study were special needs teachers different from the previous diet, namely elementary school teachers; and 3) Instruments adapted to the differences in the types of participants and tested for validity.

\subsection{The Significant Effect of Teacher Certification and Special Needs Teacher Performance}

The result shows that there is a significant effect of teacher certification on Special Needs teacher performance. This means that one of the factors influencing teacher performance is teacher certification. Certification is the process of giving educators a certificate or formal proof of recognition as professionals [32]. Certification can guarantee and provide certainty about their professional status as teachers and license or certificate holders who demonstrate certain abilities in providing educational services to the community.

The Government in Indonesia recommends that if teachers participate in the teacher certification program through the training for professional school teachers, the main objective should not be based on the professional allowance; teachers should perform their competencies according to the teacher competency standards. The Department of National Education [15] mentions the aims of the Government in conducting teacher certification as follows: (1) determining teacher eligibility in carrying out their duties as professional educators, (2) improving the process and quality of educational outcomes, (3) improving teacher's dignity, and (4) enhancing teacher professionalism. Realizing this, teachers must prepare themselves to take teacher certification. With this strategy, teacher certification will have a positive impact on quality improvement.

This study's finding is also supported by a previous study by Rida, et al. [31], and indicates that there are a correlation and significance between teacher welfare, professionalism, 
and teacher professionalism. Innovations from this study compared to previous studies include: 1) participants who are the wider research population compared to research Rida, et al. that is, this research uses five districts versus one district (previous research); 2) the participants of this study were SLB teachers different from the previous diet, namely elementary school teachers; and 3) Instruments adapted to the differences in the types of participants and tested for validity.

\subsection{The Significant Effect of Work Motivation on Special Needs Teacher Performance}

The result shows that there is a significant effect of work motivation on Special Needs teacher performance. This means that one of the factors influencing teacher performance is motivation. According to Anshel [33], motivation means an inclination and selectivity in behavior controlled by its relationship between consequences and tendencies to maintain goals until they are reached. Motivation is defined as the driving force that comes from internal and external individuals to carry out activities oriented to specific goals [19]. In other words, work motivation causes enthusiasm and/or spirit at work. Intrinsic and extrinsic motivation makes it possible to collaborate [23]. When someone is extrinsically motivated, they will take some instrumental actions [5,34]. Everyone has their own needs that encourage the desire to achieve and meet those necessities. In practice, work motivation is low due to the high job satisfaction of Special Needs teachers. However, the results of this study find that the majority of teachers' work motivation is in the high category; thus, it affects the effectiveness of the Special Needs teacher performance in conducting the teaching and learning process. It seems that the efforts of Special Needs teachers in meeting their needs encourage them to work better. The teacher's motivation improves work performance. Special Needs teachers who work professionally will be highly motivated. Also, those having high motivation in teaching will carry out their obligations enthusiastically.

The finding of this study is also supported by a previous study conducted by Cahya [35], and shows that there is a significant effect of work motivation on teacher performance. Innovations from previous studies include: 1) participants who became a wider research sample than previous research, namely five (this research) compared to one district (Cahya research); 2) participants of this study are Special Needs teachers different from research by Cahya namely physical education teachers; and 3) Instruments adjusted for different types of participants and tested for validity.

\subsection{The Significant Effects of Job Tenure, Teacher Certification, and Work Motivation on Special Needs Teacher Performance}

The result shows that there are significant effects of job tenure, teacher certification, and work motivation on Special Needs teacher performance. The $\mathrm{R}^{2}$ test result obtains a value of 0.632 . This shows that teacher performance is affected by variables of tenure, teacher certification, and work motivation (63.3\%), while the remaining $(37.0 \%)$ is influenced by other factors not included in this study.

Work performance can be improved by a person or group of people in an organization to achieve goals [36]. Special Needs teacher performance is the ability of a teacher to carry out their duties as an educator or teacher, such as learning activities, guidance, and additional relevant tasks based on the teacher's capacity to educate students to achieve learning goals set by the government. Special Needs facilitates an educational process for developing all potential students so that the teachers have a significant role.

The result shows that teacher performance is influenced by three factors, namely job tenure, teacher certification, and work motivation. The long job tenure indicates that the teacher is more experienced in teaching. Job tenure represents the work experience, knowledge, and skills of an employee. Also, the teacher's years of service are determined by job tenure as both civil servant and non-civil servant.

In addition, certification can guarantee and provide certainty about their professional status as a teacher and a holder of the license or certificate. Teachers who have already been certified show particular abilities in providing educational services to students and in improving teacher performance. Another result considered significant to improve performance is work motivation. Work motivation is encouragement or strength coming from the intrinsic and extrinsic factors, so he/she can perform well.

The finding of this study is also supported by a previous study carried out by Rida, et al. [31] and Cahya [35], showing that there is a positive correlation between work motivation, years of service, and teacher welfare and teacher professionalism. Innovations from previous studies include: 1) participants who became a wider research sample than previous research, namely five (this research) compared to one district (Cahya and Rida, et al.); 2) participants of this study are Special Needs teachers different from research by Cahya and Rida, et al. namely physical education and elementary teachers; and 3) Instruments adjusted for different types of participants and tested for validity.

\section{Conclusions}

Based on the results above, this study has practical implications. As seen there is a significant effect separately, and together, of job tenure/years of service, teacher certification, and work motivation on Special Needs teacher performance. Therefore the improvement of the 
quality performance of Special Needs teachers should be supported by job tenure, teacher certification, and work motivation.

For future research, this study provides information that variables of job tenure, teacher certification, and work motivation influence the teacher performance variable by $63.2 \%$, while the rest $(36.8 \%)$ is influenced by other factors not included in this study. Therefore, further research should be conducted by including other factors that affect teacher performance, such as education level, teacher welfare, leadership, competence, work climate, and workers' compensation. The limitation of this study is that it was conducted in a small part of Indonesia. Hence, for future research, it is also necessary to broaden the scope of the research area studied.

\section{Acknowledgments}

The author would like to thank those who have helped conduct this research.

\section{Conflict of Interest}

The authors state that there is no conflict of interest in writing this article.

\section{REFERENCES}

[1] H. Sanaky. The role of religious education in forming tolerant individuals, Indonesian Journal of Interdisciplinary Islamic Studies, Vol. 1, No. 1, 77-89, 2017

[2] W. J. Pelgrum. Obstacles to the integration of ICT in education: results from a worldwide educational assessment, Computers \& education, Vol. 37, No. 2, 163-178, 2001.

[3] I. Purnomo, T. Tomolyus, E. Burhaein. Development of learning activities playing a ball on a goal to improve manupulative skills for lower class students, Proceeding of the 1st International Conference on Science and Technology for an Internet of Things. European Alliance for Innovation, 2018 .

[4] A. Greenstein. Today's learning objective is to have a party: playing research with students in a secondary school special needs unit, Journal of research in special educational needs, Vol. 14, No. 2, 71-81, 2014.

[5] E. Burhaein. Aktivitas fisik olahraga untuk pertumbuhan dan perkembangan siswa SD, Indonesian Journal of Primary Education, Vol. 1, No. 1, 51-58, 2017a.

[6] J. M. Kauffman, D. P. Hallahan, Handbook of Special Education, Routledge, New York, 2011.

[7] I.D. Kurniawati. Masa kerja dengan job engagement pada karyawan, Jurnal Ilmiah Psikologi Terapan, Vol. 2, No. 2 , 311-324, 2014.

[8] N. K. S. Indrawati. Pengaruh masa kerja terhadap kompetensi pedagogik guru IPS SMP Negeri Singaraja tahun ajaran 2011/2012, Jurnal Pendidikan Ekonomi Undiksha, Vol 1, No. 1, 2013.

[9] E. Miranti, Y. Yacoub. Pengaruh Tingkat Pendidikan, Masa Kerja dan Motivasi Kerja terhadap Kinerja Karyawan. Jurnal Pendidikan dan Pembelajaran Khatulistiwa, Vol. 5, No. 3. $1-13,2017$.

[10] S. Aprilyanti, Pengaruh usia dan masa kerja terhadap produktivitas kerja (Studi kasus: PT. Oasis Water International Cabang Palembang). Jurnal Sistem dan Manajemen Industri, Vol. 1, No. 2, 68-72, 2017.

[11] E. Burhaein, Aktivitas permainan tradisional berbasis neurosainslearning sebagai pendidikan karakter bagi anak tunalaras. Jurnal SPORTIF: Jurnal Penelitian Pembelajaran, Vol. 3, No. 1, 55-68. (2017b).

[12] L. Latiana. Peran Sertifikasi Guru dalam Meningkatkan Profesionalisme Pendidik. Edukasi, Vol. 1. No. 1, 1-10, 2016.

[13] Undang Undang Republik Indonesia (UU RI) No. 20 tahun 2003 tentang Sistem Pendidikan Nasional.

[14] Undang-Undang Republik Indonesia (UU RI) No. 14 tahun 2005 tentang Pasal 8 dan 11 Guru dan Dosen.

[15] S. Sutopo. Faktor-faktor yang mempengaruhi kinerja guru smk bidang produktif pasca sertifikasi, Jurnal Dinamika Vokasional Teknik Mesin, Vol. 2, No. 1, 37-48, 2017.

[16] R. M. Ryan, E. L. Deci. Intrinsic and extrinsic motivations: Classic definitions and new directions. Contemporary educational psychology, Vol. 25, No. 1, 54-67, (2000).

[17] I. A. D., Pramantik, E., Burhaein. A floor time approach to improve learning outcomes of the body roll to the side in adaptive SLB learning: Classroom action research study on two cerebral palsy students. International Journal of Disabilities Sports and Health Sciences, Vol. 2, No. 2, 45-53, 2019.

[18] O. Robescu, A. G. Iancu. The effects of motivation on employees performance in organization, Valahian Journal of Economic Studies, Vol. 7, No. 2, 49-56, 2016.

[19] D. T. P. Phytanza, E. Burhaein. Aquatic Activities As Play Therapy Children Autism Spectrum Disorder, International Journal of Disabilities Sports and Health Sciences, Vol. 2, No. 2, 64-71, 2019.

[20] R. S. Weinberg, D. Gould. Foundations of sport and exercise psychology, Human Kinetics, Champaign, 2011.

[21] S. J. Yoo, S. H., Han, W. Huang. The roles of intrinsic motivators and extrinsic motivators in promoting e-learning in the workplace: A case from South Korea. Computers in Human Behavior, Vol. 28 No. 3, 942-950, 2012.

[22] J. M. Harackiewicz, C. Sansone. Intrinsic and Extrinsic Motivation the Search for Optimal Motivation and Peformence, Academic Press, California, 2000.

[23] B. M. Taylor. The integrated dynamics of motivation and performance in the workplace, Performance Improvement, Vol. 54, No. 5, 28-37, 2015.

[24] J. R. Fraenkel, N. E. Wallen, H. H. Hyun. How to Design and Evaluate Research in Education. McGraw-Hill, New York, 
2011.

[25] J. Cohen. Weighted kappa: Nominal scale agreement provision for scaled disagreement or partial credit. Psychological bulletin, Vol. 70, No. 5, 213-220, 1968.

[26] F. Koesindratmono, B. G. Septarini. Hubungan antara masa kerja dengan pemberdayaan psikologis pada karyawan PT. Perkebunan Nusantara X (Persero), Insan, Vol. 13, No. 1, 50-57, 2011.

[27] D. Guile, T. Griffiths, Learning through work experience. Journal of education and work, Vol. 14, No. 1, 113-131, 2001.

[28] E. Miranti, Y. Yacoub. Pengaruh Tingkat Pendidikan, Masa Kerja dan Motivasi Kerja terhadap Kinerja Karyawan, Jurnal Pendidikan dan Pembelajaran Khatulistiwa, Vol. 5, No. 3, $1-13,2016$

[29] S. Aprilyanti. Pengaruh usia dan masa kerja terhadap produktivitas kerja (Studi kasus: PT. Oasis Water International Cabang Palembang), Jurnal Sistem dan Manajemen Industri, Vol. 1, No. 2, 68-72, 2017.

[30] D. T. P. Phytanza, E. Burhaein, Sukoco, W. S. Ghautama. Life Skill Dimension Based on Unified Sports Soccer Program in SLB of Intellectual Disability. Yaşam Becerileri Psikoloji Dergisi, Vol. 2, No. 4, 199-205, 2018.
[31] M. Rida, N. Dantes, K. R. Dantes. Hubungan motivasi kerja, masa kerja, dan kesejahteraan guru dengan profesionalisme guru Sekolah Dasar Negeri di Kecamatan Grabag Kabupaten Magelang, e-Journal Program Pascasarjana Universitas Pendidikan Ganesha Vol. 3, No. 1, 1-10, 2013.

[32] B. Kartowagiran. Kinerja guru profesional (Guru pasca sertifikasi), Jurnal Cakrawala Pendidikan, Vol. 3, No. 3, 463-473, 2011.

[33] Komarudin. Psikologi Olahraga, PT Remaja Rosdakarya, Bandung, 2015.

[34] F. Mustofa, M. Mansur, E. Burhaein. Differences in the effect of learning method massed practice throwing and distributed practice on learning outcomes skills for the accuracy softball, Vol. 4, No. 2, 213-222, 2019.

[35] R. D. Cahya. Pengaruh Kompensasi, Iklim Kerja dan Motivasi Kerja terhadap Kinerja Guru Penjaskes SMP di Bandar Lampung, Master Thesis, Universitas Lampung, 2016.

[36] S. Basuki. Hubungan Pelaksanaan Supervisi, Budaya Sekolah, Semangat Kerja, dan Motivasi Kerja dengan Kinerja Guru Pendidikan Jasmani pada Sekolah Dasar Negeri di Kalimantan Selatan, Master Thesis, Universitas Malang, 2015. 